\title{
Silver/Bismuth/Nafion Modified Pencil Graphite Electrode for Trace Heavy Metal Determination
}

\author{
Shirley Palisoc ${ }^{1,2}$, Ella Mae Espique ${ }^{1}$, Alein Marimel Ribay ${ }^{1}$, Steffanie Sy $^{1}$, Kyelle Ardelle Tan ${ }^{1}$, \\ Nico De Jesus ${ }^{1}$, Marissa Noel ${ }^{3}$, Michelle Natividad ${ }^{1,2, *}$ \\ ${ }^{1}$ Condensed Matter Physics Laboratory, De La Salle University, Manila, Philippines, 922 \\ ${ }^{2}$ Condensed Matter Research Unit, CENSER, De La Salle University, 2401 Taft Avenue, Manila, \\ Philippines, 922 \\ ${ }^{3}$ Chemistry Department, De La Salle University, 2401 Taft Avenue, Manila, Philippines, 922 \\ *E-mail: michelle.natividad@dlsu.edu.ph
}

doi: $10.20964 / 2018.11 .63$

Received: 11 July 2018 / Accepted: 6 September 2018 / Published: 1 October 2018

A low-cost modified pencil graphite electrode (PGE) was developed for the determination of trace heavy metals in wastewater. Graphite rods $(2 \mathrm{HB})$ of $3 \mathrm{~mm}$ diameter from a commercial brand of pencils were modified by varying amounts of silver nanoparticles (AgNP) and bismuth (Bi) mixed in a solution of $1 \%$ Nafion $^{\circledR}$ and isopropanol via the drop coating technique. The PGE modified by $3 \mathrm{mg}$ AgNP and $2 \mathrm{mg}$ Bismuth was deemed the best electrode as it yielded the highest anodic peaks as determined by anodic stripping voltammetry (ASV). By optimizing the ASV parameters, it was determined that the optimum accumulation time and deposition time are 120s and 15s, respectively. The calibration curve was used to determine the limits of detection which were 0.19 parts per billion (ppb) for $\mathrm{Cd}^{2+}$ and $0.30 \mathrm{ppb}$ for $\mathrm{Pb}^{2+}$ while the limits of quantitation were $568 \mathrm{ppb}$ for $\mathrm{Cd}^{2+}$ and 894 $\mathrm{ppb}$ for $\mathrm{Pb}^{2+}$. The Pearson coefficients of the calibration plots of $\mathrm{Cd}^{2+}$ and $\mathrm{Pb}^{2+}$ are 0.9822 and 0.9569 , respectively. Wastewater samples were collected and analyzed for trace heavy metals using the optimized electrode.

Keywords: anodic stripping voltammetry, pencil graphite electrode, bismuth, silver nanoparticles, Nafion ${ }^{\circledR}$

\section{FULL TEXT}

(C) 2018 The Authors. Published by ESG (www.electrochemsci.org). This article is an open access article distributed under the terms and conditions of the Creative Commons Attribution license (http://creativecommons.org/licenses/by/4.0/). 